\title{
Qualitative study of disaster preparedness in an Indonesian village: Interviews with survivors of flash flooding near Bandung
}

Abstract

Debris flows and flash floods pose a continuing hazard to Nyalindung, a village in a mountainous part of West Java. On 16 December 2013, three days of heavy rain and a partial breaching of a succession of landslide dams triggered a debris flow and flash flood. One person died, nine homes were damaged, and 53 residents were evacuated. We asked villagers who were directly affected by that disaster about their knowledge of the hazard, in the hope of developing adaptation strategies. The survey showed that the majority of the villagers first became aware of the hazard during the 2013 disaster. Practical solutions exclude relocation because the village has stood in flow paths for the past 70 years or more, and because the families residing there are attached to the land and each other. We recommend combining public education about existing hazards with early warning technology.

Keywords

Flash flood • landslide dam • Indonesia • public education • early warning technology

(C) University of Warsaw - Faculty of Geography and Regional Studies
Iwan Gunawan Tejakusuma

Euthalia Hanggari Sittadewi

Center of Technology for Disaster Risk

Reduction, BPPT JI. M. H. Thamrin No. 8 ,

Jakarta 10340, Indonesia

e-mail: iwan.tejakusuma@gmail.com

e-mail: sittadewi57@gmail.com

\section{Introduction}

Indonesia, the fourth most populous country on Earth, is regularly threatened with debris flows and flash floods. The threat is increasing with continued population growth and climate change that makes intense rainfall more common. Reducing the risk from infrequent natural catastrophes became a national priority in the wake of the 2004 Indian Ocean tsunami, but without much attention paid to the chronic threat of debris flows and flash floods.

These problems have prompted us to survey disaster preparedness in an Indonesian village after it had been damaged by a flash flood from a landslide dam in 2013. The physiographic setting exposes the village to more of such floods in the future. We interviewed ten of the survivors of the 2013 disaster, in search of insights that would improve the prospects for adapting to the hazard, both in this village and in others nationwide. This paper describes the village, summarises the 2013 disaster, presents survey methods and results, and shows how local knowledge could be complemented with an early warning system.

\section{Previous Work}

Debris flows and flash floods in Indonesia

Debris flows and flash floods are frequent in many parts of Indonesia. They have caused disasters not only on the country's most populated island, Java Island, but also in Sumatra (Sumatera), Sulawesi, and Papua. Examples since 2005 attest to the enormity of this national risk:

- On 1 January 2006, a flash flood hit the Jember area of East Java, leaving 51 dead and 30 injured.

- On 4 November 2011, debris flows and floods occurred in West Sumatera. In Pesisir Selatan Regency, they caused three deaths and damaged 42 houses. Elsewhere in the region, ten out of 12 districts were affected, six people died, 51 houses were destroyed and 295 houses were damaged. A flash flood was preceded by seven days of rainfall.

- On 4 October 2012, in Papua, Wasior District, Wondama Bay, a combination of landsliding and a flash flood left 169 people dead, 105 severely injured, and 3,374 with lesser injuries. A total of 9,016 survivors were evacuated.

- On 15 January 2014, in an eastern part of Indonesia, a flash flood unexpectedly hit the capital city of North Sulawesi Province, Manado. This event resulted in 25 fatalities. Thousands of houses were flooded and 40,000 people were forced to evacuate.

These examples notwithstanding, preparedness for debris flows and flash floods in Indonesia has received little attention. Few studies have linked preparedness to both geological and social conditions. Rahardjo et al. (2013) and Istijono and Umar (2013) emphasised the physical aspects of the Sulawesi and Sumatera flash floods. Hardjosuwarno (2014), Sumaryono and Hildasari (2010) considered hazards and mitigation options for flash floods and debris flows along the upper Jeneberang River in South Sulawesi, and on the flanks of Mount Merapi, Central Java, respectively. Adi (2013) reported low levels of preparedness in areas affected by flash floods in 2012.

An uncommonly thorough investigation was carried out by Wardhono et al. (2010) on the 2006 flash flood disaster in Jember. Disaster risk was mapped, community capacity was assessed, and risk perception was analysed as well. This work goes beyond 
what has been attempted in studies of flash flood disasters in Manado, Sulawesi, and Papua.

Debris flows and flash floods in other countries

We have read but a small fraction of the vast scientific literature on debris flows and flash floods outside Indonesia. Notable findings include:

Disaster education, awareness and knowledge are crucial factors in minimizing casualties (Luo et al. 2014, Chiba 2011). Conversely, inadequate public awareness, lack of disaster preparedness, weak governance, lack of coordination among the concerned government agencies, insufficient financial resources, and deficient technical knowledge contribute to the loss of life and property through natural disasters (Tuladhar et al. 2015). Poor people tend to be the most vulnerable (Santi et al. 2011).

Enhancing community resilience is key to reducing vulnerability in the face of natural hazards (López-Marrero \& Tschakert 2011). Disaster preparedness that is based on adaptive and agile approaches, and which incorporates network analyses, partnerships, and new technologies, is a crucial element in effective risk management in a complex urban system (Carpenter and Grunewald 2016). In the Puerto Rican examples described by López-Marrero and Petra (2011), enhancing community resilience to flooding required the support for social learning by building on existing knowledge, stressing the importance of developing a diverse set of flood management options, and promoting effective linkages and collaborations between community members and emergency managers to encourage collective flood management.

These assorted findings from other countries reinforce the common-sense view that disaster preparedness can reduce disaster risk. In that spirit, we surveyed the potential for using disaster preparedness to minimise the loss of life and property as a consequence of debris flows and flash floods in Indonesia.

Setting of the Investigated Area

Physical geography

Landslide, debris flows and flash floods increasingly threaten Indonesia as the nation's population continues to grow and the region's climate changes. The threat arises when bursts of heavy rainfall on deforested hillsides, particularly in Java, where the rainy season usually occurs in December, January, and February.

The research area is located in Bandung Barat Regency, a largely mountainous area centred about 7 degrees south of the equator. It contains 15 administrative districts, one of which is Cisarua District. The average altitude of this district is 110 meters, with the maximum height of 2,243 meters above sea level. Slopes range from flat to those exceeding $45 \%$. A large fraction of the land is cultivated. Cisarua District is northwest of the city of Bandung, the capital city of West Java Province. From Bandung, the district can be reached by road, with a travel distance of about 18 kilometres.

Nyalindung, the site of a 2013 flash-flood disaster, is located inside a valley beside Mount Burangrang. The village lies about 1,262 meters above sea level, about 2,550 meters laterally from the summit of Mount Burangrang, which stands about 575 meters higher than the village. The stream in Nyalindung is perennial but during the dry-season the discharge is relatively small. The persistence of stream flow during the dry season most likely reflects the presence of forest vegetation in the catchment upstream has been conserved to some degree.

Cultural geography

The soil in the vicinity of the village appears to be fertile suitable especially for horticulture cultivation such as cabbage, broccoli, paprika, pumpkins, and tomatoes. The people use the land nearby, either on the slopes or on top of the hill. Some thirty years ago, the area near the stream was paddy fields irrigated by the stream's flow. As the population grew, the paddy fields became occupied by houses, vegetable plots, and livestock. Houses are not supposed to be built on paddy fields, but people did so because of the proximity to water, cultivation areas, and their relatives.

According to the data of the BPS - Statistics of Bandung Barat Regency (2016), Cisarua District has an area of 55.11 hectares and an average altitude of 1,100 meters above sea level. The district consists of eight villages, 104 RW (Rukun Warga, a group of $\mathrm{RT}$ ) and $395 \mathrm{RT}$ (Rukun Tetangga, a group of houses). The total population of Cisarua District in 2015 was 72,521 people, closely divided between male and female. In the Tugumukti Town, which includes Nyalindung, the population was 6,157.

As of October 2015, 669 people were counted as the population of Nyalindung. The area affected by the 2013 flashflood disaster in Nyalindung was RW 10. Of this population, one person is disabled and another one person is blind. There were 328 males and 331 females, 33 children under five years old, and 12 senior citizens. The residents of Nyalindung make their living by horticultural farming in green houses and directly on the hillside. Hillside farming began about 35 years ago. We checked for evidence of farming practices that would help prevent landslides. In Bali, such practices are known as subak. We found no evidence for this kind of strategy in Nyalindung.

\section{3 debris flow and flash flood disaster}

Debris flows and flash floods are not new to the area of Nyalindung. Most of the village houses lie along the valley exactly on top of an unconsolidated debris flow deposit that we identified in a geological reconnaissance. The deposit contains boulders in a sandy matrix. It was deposited long before 2013 along the path of a stream which flows near the top of Mount Burangrang. Human settlements have spread across this pre-2013 debris flow very close to the recent stream. The valley containing those deposits is about 45 meters wide.

The 2013 disaster resulted from the village's first large flash flood in about 50 years. Flooding also occurred in 2011, but this event was not severe and did not trigger landslides.

The 2013 disaster, on December 16, caused one death, damaged nine homes, and forced 53 residents to evacuate. The disaster was occasioned by three days of heavy rains that caused a series of landslides to occur in the upstream area. The landslide materials dammed the stream, and when the dam was partly breached a debris flow ensued. The debris flow evolved downstream into a flash flood, which entered Nyalindung. The waters carried sediment, but most of the heavy material, fraction of boulders, cobbles and pebbles had been left behind as the flow moved toward the village. The disaster thus resulted from a chain of natural events: days of heavy rain, landslides that dammed a stream in the mountainside catchment above the village, debris flows from breaching of the landslide dam, and a downstream phase change from slurry to flash flood as the flows approached Nyalindung.

\section{Methods}

An in-depth interview used a questionnaire about the 2013 disaster, prior knowledge of landslides and flash floods, and village history. Among 53 persons directly affected by the 2013 disaster, ten people from different families were included in the interviews. This sample was deemed sufficient for qualitative descriptive research, in which a minimum of $10 \%$ of the population should be included (Gay \& Diehl 1992). The purposive sampling method was used in this research. Selected respondents were people in Nyalindung who lived in the pathway of flash flood. 


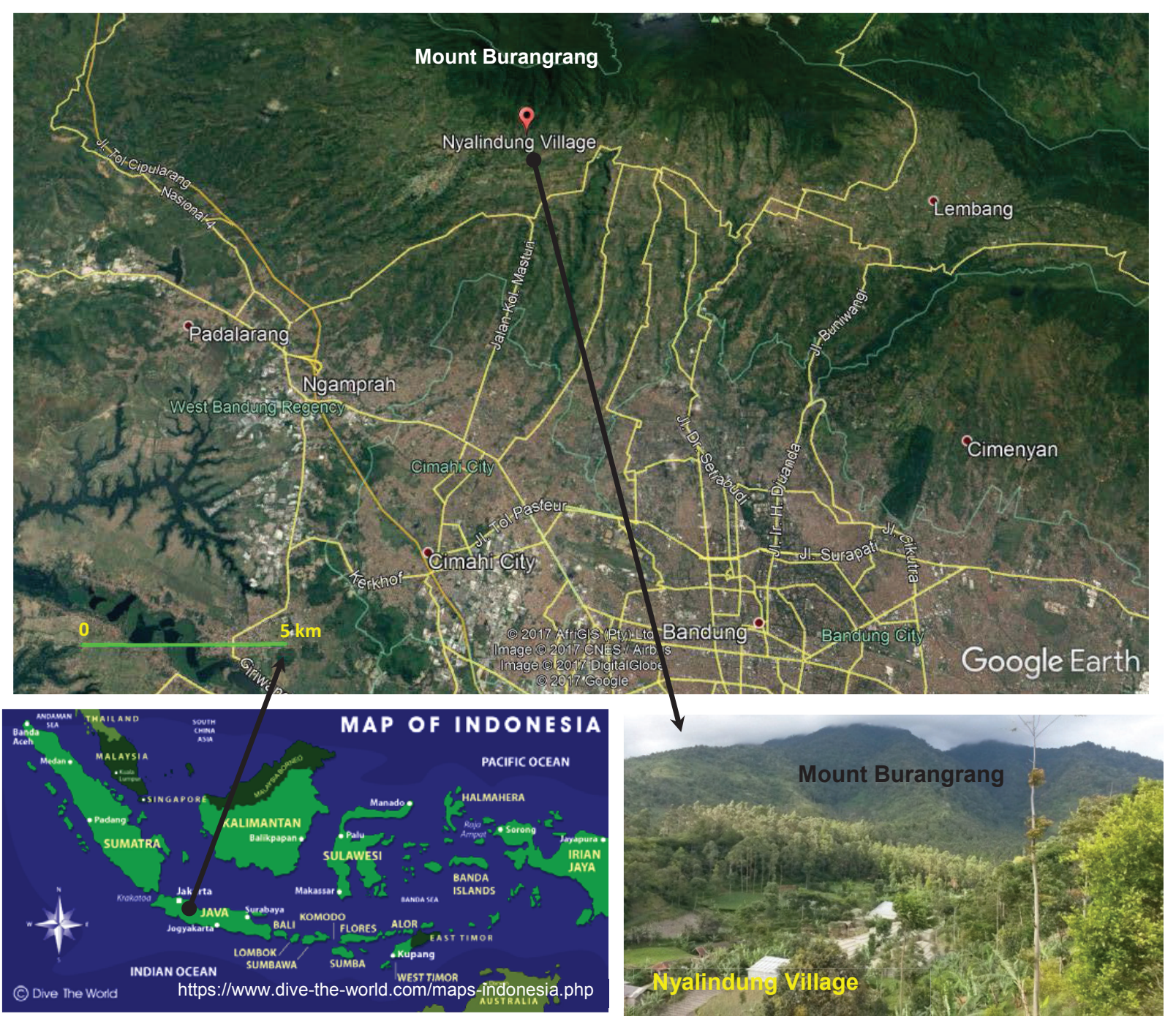

Figure 1. Nyalindung is located in a small river valley (in the foreground). The debris flow originated from Mount Burangrang, in the upstream valley in the background, and continued as flash flood that flowed through the village. The background image was taken from Google Earth Source: Top: Google Earth; Bottom left: https://www.dive-the-world.com/maps-indonesia.php; Bottom right: Author

We adopted several indicators of disaster preparedness of Sutton and Tierney (2006): knowledge and attitudes on disaster, emergency response plan, early warning system, available resources and social capital. Resources are divided into three parts: human resources, financial resources or logistics, and materials providing technical guidance. By supporting resources, we mean tangible objects that can be used to help a community recover from a disaster. This indicator is generally viewed as the various resources required by individuals or communities in the recovery effort or to survive in the conditions of disaster or emergency. The resources can originate from within or outside of the affected areas.

\section{Survey Results}

The findings reported in this section are based on our survey and interviews about disaster preparedness in Nyalindung. This field work assessed local knowledge about the potential for landslide upstream and an ensuing debris flow and flash flood. Ten respondents who were directly affected by the flash floods, living in areas known as RW 10, RT 04 and RT 03, were chosen. The results of the interviews reveal important limitations of community knowledge to the flash floods of December 2013. The results also provide information on the utilisation of handphones during the disaster event. The results of the interview are presented in figure 2 .

Local Community Knowledge About Landslide and Flash Flood Disaster

Local wisdom develops according to specific locations which include topography, climate and environmental conditions. It is part of the local culture that is developed and used by the local community as a disaster management tool.

The interview results showed that more than half of the respondents were unaware of pre-2013 landslides and flash floods. However, one-third of the respondents heard of such disasters from their ancestors, and one respondent had direct experience with landslides and flash floods. These findings suggest that the local community as a whole was ill-prepared for the 2013 disaster. The penultimate flash flood disaster occurred about 50 years ago, too long ago for most residents to know about it. In terms of local knowledge about the vulnerability of the area to landslides and flash floods, half of the respondents knew that 
MISCELLANEA GEOGRAPHICA - REGIONAL STUDIES ON DEVELOPMENT

Vol. $21 \cdot$ No. 4 • 2017 • pp. 179-183 • ISSN: 2084-6118 • DOI: 10.1515/mgrsd-2017-0028

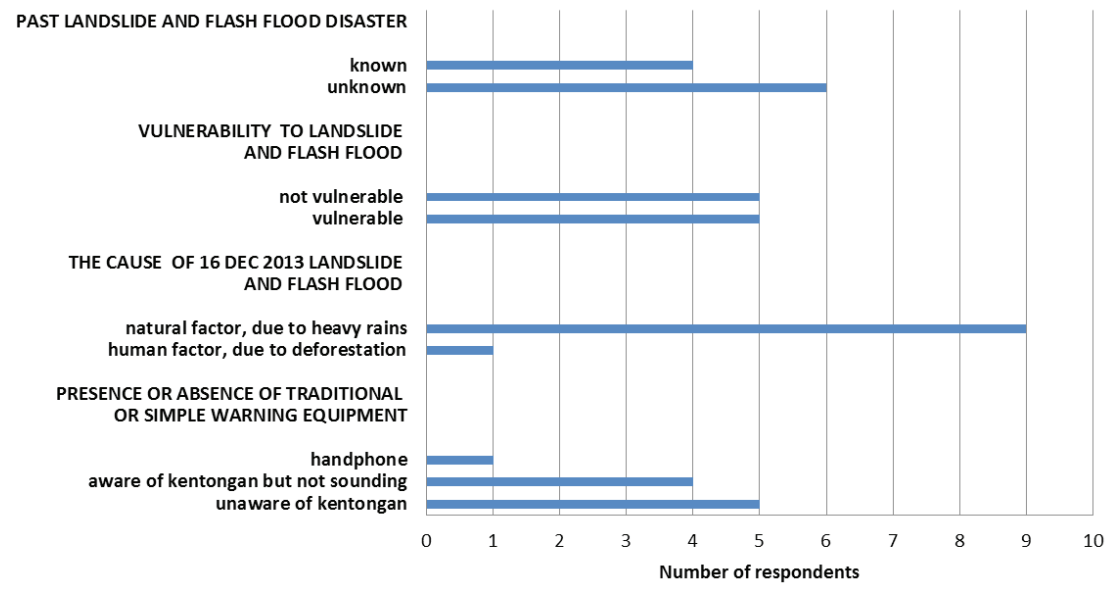

Figure 2. Nyalindung community knowledge and facts on landslide and flash flood disaster Source: Results of interviews with ten people directly affected by 2013 debris flow-flash flood disaster.

the area is prone to landslides and flash floods while the other half did not. Although half of the respondents said the area is prone to disasters, the long period of time since the penultimate disaster lowered the expectations that a similar disaster would recur.

We also surveyed perceptions of the causes of the flash flood in December 2013. Of the ten respondents, only one believed that flash floods resulted from human activities like deforestation in the upstream area. Instead, the vast majority attributed the flash flood to natural factors, particularly the prior three days of heavy rain. This opinion was supported by one of the respondents who explained that landslide had occurred in the upstream before the flash flood and the landslide debris accumulated in the stream in an area of approximately two hectares. Apparently, the debris dammed the stream, and when the heavy rain continued, partial breaching of the dam released a slurry that reached the village as a flash flood.

\section{Supporting Resources}

The interviews provided evidence for stockpiling of emergency rations and for a limited use of warning devices. It was found that people of Nyalindung store rice in a storehouse for use only during emergency situations. We also asked whether traditional percussion instruments (metal gong and wooden, cylindrical kentongan) and more modern equipment (loud speaker, mobile phone) had been used by local people to inform or forewarn one another during the 2013 disaster. Of the ten respondents, half of them said that no warning had been sounded, and less than half recalled that while there were kentongan for warning, no kentongan sound had been heard during the disaster. Only one respondent reported using a mobile phone to notify relatives of a hazard. Overall, there was hardly any warnings given to or by the people of Nyalindung during the disaster, notwithstanding the availability of simple communication tools like the kentongan and mobile phones.

We asked several residents about the possibility of relocating their homes to places away from the stream. These respondents said that while they cannot afford the relocation by themselves, they would consider relocating if there were funding and support from the local government. However, the relocation would need to include their relatives.

\section{Early Warning System}

Despite living in an area of debris flow and flash flood high-risk zone, the people of Nyalindung do not possess an early warning system of any kind. Therefore, we recommended complementing their increased awareness with a landslide and flash flood early warning system. Instrumentation for the debris flow and flash flood early warning system would include sensors that would forewarn the villagers of debris flows from the mountainside above them. Interviews showed that the residents of Nyalindung, along with leaders at the RW and RT levels, would welcome the installation of such early warning technology.

\section{Social Capital}

Social capital, as the ability of individuals or groups to cooperate with other individuals or groups, can be used as an indicator of community preparedness. Communities or individuals who have better social relationships with each other will find it easier to prepare for a disaster. In Nyalindung, a youth organisation, Karang Taruna, was founded before the 2013 flash flood and has since expressed its readiness to help. After the flash flood, the residents established a Society for Disaster Management, KMPB (Keluarga Masyarakat Penanggulangan Bencana), and a Community Preparedness Forum, FKDM (Forum Kesiapsiagaan Dini Masyarakat). Interviews have shown the importance of increasing community resilience and capacity building in Nyalindung. The steps that could be taken include public education and training on debris flow and flash flood hazards, and development of evacuation routes.

\section{Emergency Response Plan}

An emergency response plan is an important element in disaster preparedness. Planning for evacuation, relief, and rescue activities can minimize victim numbers. Since the 2013 flash flood, Nyalindung has developed evacuation routes and designated evacuation sites. The local government, through a programme of disaster resilient villages, has on one occasion conducted training and simulation for the community. This programme needs to be sustained and enhanced.

\section{Conclusions}

It is hoped that these findings will lead to fewer losses from future debris flows and flash floods in Nyalindung. Since its founding more than 70 years ago, the village has subsisted mainly on rice and vegetable farming, with few interruptions by flash floods and landslides. A prior disaster about 50 years ago was known only to a few of the people interviewed. The unusual effects of the 2013 disaster found the community ill-prepared. With climate change, the flash-flood hazard in Nyalindung is 
likely to increase. Lessons from the 2013 disaster, including those highlighted in our interviews, may contribute to local knowledge and inform local actions.

After the 2013 disaster, the residents established a Society for Disaster Management. They began storing rice in the storehouse for emergency use only. The local government, through a programme of disaster resilient villages, initiated disaster training, a programme which requires further development. There is no expectation of moving the village outside the area of the flash flood hazard. This would be too costly for the villagers and the cost would need to cover the relocation of their relatives. Although exposed to a repeat of the 2013 disaster, the people of Nyalindung appear to be better prepared. Therefore, the most promising strategy for risk reduction combines the recent preparedness efforts with early warning technology that has yet to reach the village.

\section{References}

Adi, S 2013, 'Characterisation of flash flood disaster in Indonesia', Jurnal Sains dan Teknologi Indonesia, vol. 15, no. 1, pp. 42-51.

BPS - Statistics of Bandung Barat Regency 2016, Bandung Barat Regency in figures, Statistics of Bandung Barat Regency.

Carpenter, S \& Grunewald, F 2016, 'Disaster preparedness in a complex urban system: the case of Kathmandu Valley, Nepal', Disasters, vol. 40, issue 3, pp. 411-431.

Chiba, M 2011, 'Warning and evacuation in response to sedimentrelated disasters', Natural Hazards, vol. 56, issue 2, pp. 499-507.

Gay, RL \& Diehl, PL 1992, Research methods for business and management, Macmillan Publishing Company, New York: Macmillan Pub. Co.; Toronto: Maxwell Macmillan Canada; New York: Maxwell Macmillan International.

Hardjosuwarno, S 2014, 'Overall simulation of early warning system against debris flow in the Upper Jeneberang River, South Sulawesi, Indonesia'. International Journal of Academic Research, vol. 6, issue 2, pp. 156-163.

Istijono, B \& Umar, Z 2013, 'Disaster management on construction of debris flow and estuary of Kambang River in West Sumatra', Proceeding the 6th civil engineering conference in Asia Region: embracing the future through sustainability, Jakarta, pp.50-56.

López-Marrero, T \& Tschakert, P 2011, 'From theory to practice: building more resilient communities in flood-prone areas', Environment and Urbanization, vol. 23, no. 1, pp. 229-249.

Luo, Y, Shaw, R, Lin, H \& Joerin, J 2014, 'Assessing response behaviour of debris-flows affected communities in Kaohsiung, Taiwan', Natural Hazards, vol. 74, issue 3, pp. 1429-1448.

Rahardjo, AP, Legowo, D, Istiarto, Kurniawan YT \& Hardjosuwarno, S 2013, 'Case study on 2006 flash flood disaster in Putih River of Jember, East Java, Indonesia', in Advances in River Sediment Research eds. S Fukuoka, H Nakagawa, T Sumi \& H Zhang, CRC Press, pp. 129-136. Available from: <https:// repository.ugm.ac.id/34914/>. [24 January 2017].
Santi, PM , Hewitt, K, Van Dine, DF \& Barillas CE 2011, 'Debrisflow impact, vulnerability and response', Natural Hazards, vol. 56 , issue 1 , pp. 371-402.

Sumaryono, A \& Hildasari, E 2010, The development of Sabo technology to mitigate disaster caused by debris flow in Indonesia. Available from: <http://www.interpraevent.at/ palm-cms/upload_files/Publikationen/Tagungsbeitraege/ 2010_910.pdf>. [22 February 2017]

Sutton, J \& Tierney, K 2006, Disaster Preparedness: Concepts, Guidance and Research, Colorado, Natural Hazards Center Institute of Behavioral Science, University of Colorado, Boulder, CO. Available from: <http://www.fritzinstitute.org/ pdfs/whitepaper/disasterpreparedness-concepts.pdf>. [12 December 2016].

Tuladhar, G , Yatabe, R, Dahal, RK \& Bhandary, NP 2015, Disaster risk reduction knowledge of local people in Nepal. Available from: <https://www.researchgate. net/publication/276385116_Disaster_risk_reduction knowledge_of_local_people_in_Nepal>. [24 January 2017].

Wardhono, A, Rondhi, M, Irawan, JF, \& Prakoso, B 2010, Identification and mapping of disaster risk of flash floods in Jember Regency East Java Indonesia. Available from: $<$ https://scholar.google.co.id/citations?user=4uhK2N4AAAA J\&hl=en>. [2 February 2017]. 